\section{Analysis of the Color and Fluorescence Alterations of Enamel and Dentin Treated With Hydrogen Peroxide}

\author{
Taciana Marco Ferraz Caneppele, Carlos Rocha Gomes Torres, Eduardo Bresciani
}

Department of Restorative Dentistry, Institute of Science and Technology, UNESP - Univ Estadual Paulista, São José dos Campos, SP, Brazil

Correspondence: Taciana Marco Ferraz Caneppele, Avenida Engenheiro Francisco José Longo, 777, 12245000 São José dos Campos, SP, Brasil. Tel: +55-12-3947-9304. e-mail: taciana@ict.unesp.br

Key Words: tooth whitening, color, fluorescence, hydrogen peroxide.

\section{Introduction}

Fluorescence is the property of a substance by which it absorbs light and spontaneously emits it at a longer wavelength. In dentistry, fluorescence has been assumed to be the absorption of ultraviolet light (UV) radiation by a substance and emission of visible light in the blue spectral region. According to Spitzer and Ten Bosch (1) natural tooth emits a strong blue fluorescence under UV light.

In 1928, Benedict (2) reported that the fluorescence of enamel and dentin could be obtained by excitation with UV light. Since then, many researchers have studied fluorescence. Hoerman and Mancewicz (3) reported that the phosphorescence of calcified tissues is derived mainly from organic content and the relative fluorescence intensity of enamel is $1 / 3$ of that observed in dentin. Armstrong (4) suggested that the fluorescence in dentin may originate from inorganic complexes with some organic compounds. Foreman (5) found in dentin two fluorophores, tryptophan and other unknown amino acid. Hafstrom-Björkman et al. (6) found no differences in fluorescence between bovine and human enamel, and also that organic and inorganic components of enamel contributed to its fluorescence.

Tooth whitening is a procedure that involves changing the optical properties of dental tissues, such as color, translucency and fluorescence (7-9). Assessing fluorescence in teeth submitted to whitening procedures, Gotz et al.(7) evaluated the effect of tooth whitening on enamel surface and subsurface, including the study of subsurface histomorphology, micro-chemical composition and changes in fluorescence. A decrease in fluorescence was observed after whitening, assessed by Raman spectroscopy combined with laser scanning confocal microscopy. The authors detected the phenomenon, reporting no reasonable explanation, suggesting further studies to understand it. Caneppele (8) also observed a decrease in fluorescence after tooth whitening. The indirect method of color assessment for inclusion and exclusion of the UV component of D65 illuminant was used. Jiang et al. (10) investigated the effect of $30 \%$ hydrogen peroxide on human enamel by Raman scattering and laser-induced fluorescence. That study observed a large reduction in fluorescence of enamel after immersion in 30\% hydrogen peroxide and suggested that the organic component of enamel is strongly affected by hydrogen peroxide.

Hydrogen peroxide can be applied directly on tooth, diffuse trough tooth enamel to reach the enamel-dentinal junction and dentine regions (11-13). In alkaline conditions, hydrogen peroxide acts as a strong oxidizing agent forming free radicals that may eliminate chromophores by either cleaving double bonds in organic molecules or oxidizing their chemical moieties, resulting in soluble molecules (14).

There is no consensus about the effect of whitening on fluorescence of dental tissues, as well as which components of enamel and dentin are responsible for the fluorescence.

The objective of this study was to evaluate the effect of whitening on the fluorescence and color of the enamel and dentin substrates. The null hypotheses tested were: whitening with hydrogen peroxide does not affect color of enamel and dentin; whitening with hydrogen peroxide does not affect fluorescence of enamel and dentin. 


\section{Material and Methods}

\section{Specimen Preparation}

Fifty extracted, non-damaged and intact bovine incisors were stored in $0.1 \%$ thymol solution at room temperature until required. A single enamel or dentin specimen, presenting $6 \mathrm{~mm}$ in diameter and $1 \mathrm{~mm}$ high, was obtained from the labial surface of each crown using a trephine mill (F.N. Moraes, São José dos Campos, SP, Brazil) and polishing paper (Extec, Essington, PA, USA).

\section{Fluorescence Analysis}

Fluorescence measurements were performed with the RF-5301 PC (Shimadzu Corp., Kyoto, Japan) spectrofluorophotometer with excitation wavelength at $365 \mathrm{~nm}$. The emission spectrum ( 400 to $600 \mathrm{~nm}$ ) was obtained and the value of emission peak in Fluorescence Units (F.U.) and wavelength were recorded using the "peak pick" tool of specific software (RFPC - Shimadzu).

\section{Color Analysis}

Prior to treatment, the baseline color values of each specimen were assessed under standardized ambient conditions according to the CIE L*a*b* system, using a spectrophotometer (CM2600d; Konica Minolta, Osaka, Japan) with an integrating sphere. The device was adjusted to use the D65 standard light source with 100\% UV included and specular reflection included (SCI). The observer angle was set at $2^{\circ}$ and the device was adjusted to a small reading area (SAV). The color of each sample was measured 3 times and averaged. The results of color measurements were quantified in terms of three coordinate values $\left(L^{*}\right.$, $\left.a^{*}, b^{*}\right)$, as established by the Commission Internationale de I'Eclariage (CIE), which locates the color of an object in a three-dimensional color space. $L^{*}$ axis represents the degree of lightness within a sample and ranges from 0 (black) to 100 (white). The $a^{*}$ axis represents the degree of green/red color, while $b^{*}$ axis represents the degree of blue/yellow color of the sample.

The color was measured over a white (L:84.95; a:-0.38; $\mathrm{b}: 2.93)$ standard background.

From the color measurements at baseline and those after the whitening procedures, the values of the changes of $\mathrm{L}^{*}(\Delta \mathrm{L}), \mathrm{a}^{*}(\Delta \mathrm{a})$ and $\mathrm{b}^{*}(\Delta \mathrm{b})$ were calculated. Next, the total change color or the variation in color perception of each specimen was calculated, designated by the abbreviation $\Delta \mathrm{E}^{*} \mathrm{ab}$. This parameter was calculated according to the following formula:

$$
\Delta \mathrm{E}^{*} \mathrm{ab}=\left(\Delta \mathrm{L}^{2}+\Delta \mathrm{a}^{2}+\Delta \mathrm{b}^{2}\right)^{1 / 2}
$$

\section{Tooth Whitening}

After baseline measurement of fluorescence and color, the specimens were immersed in a $35 \%$ hydrogen peroxide solution for $1 \mathrm{~h}$ and were further washed in running water for $1 \mathrm{~min}$. The whole process was repeated after 7 days.

In clinical situations, enamel surface is fully exposed to whitening agents, while exposure of dentin occurs via diffusion of hydrogen peroxide through the enamel-dentine junction to reach dentin region. In cases of defective restorations or whitening of non-vital teeth, dentin may be directly exposed to the whitening agent. For this reason, it is important to examine the effect of oxidizing agents on dentin and enamel. Thus, in this study was evaluated the effect of whitening on the fluorescence and color of enamel and dentin, by direct application of whitening agent over enamel and dentin.

Between immersions in 35\% hydrogen peroxide, specimens were stored in deionized water and $24 \mathrm{~h}$ after the second application of hydrogen peroxide, final color and fluorescence measurements were performed.

\section{Chemical Characterization}

In order to determine concentration of chemical elements in the specimens, 5 additional specimens of ach group were submitted to energy dispersive spectrometry (EDS) (JSM-5310; JEOL, Tokyo, Japan) before and after the whitening procedure. Operating conditions were as follows: $20 \mathrm{kV}$ accelerating voltage, $30-45 \mathrm{~s}$ counting times with a $35 \mathrm{~mm}$ working distance. The atomic percentage of the following elements was recorded: carbon (C), calcium (Ca), phosphorus $(\mathrm{P})$ and oxygen $(0)$. The following element ratios were calculated for each substrate: $\mathrm{C} / \mathrm{Ca}, \mathrm{C} / \mathrm{P}, \mathrm{O} / \mathrm{C}$ and $\mathrm{Ca} / \mathrm{P}$.

\section{Statistical Analysis}

For fluorescence, repeated measures analysis of variance and Tukey's test were conducted. For color, $\Delta \mathrm{L}, \Delta \mathrm{a}, \Delta \mathrm{b}$ and $\Delta \mathrm{E}$ data were statistically analyzed using unpaired t-test to compare enamel and dentin results. For chemical characterization, $t$ test was used to assess differences after whitening therapy within substrates for each ratio. The significance level was set at $p<0.05$.

\section{Results}

\section{Fluorescence}

The overall fluorescence measurements of the specimens at baseline and after whitening for all experimental conditions are shown in Table 1. The cross-product substrate vs whitening as well as the factors substrate and whitening were statistically significant $(p=0.001)$.

Figures 1 and 2 show averaged fluorescence emission spectrum of enamel and dentin, before and after whitening, at $365 \mathrm{~nm}$ excitation.

In both substrates an emission peak of fluorescence was observed in the $440-450 \mathrm{~nm}$ region, wavelengths that are near to blue (410-460 $\mathrm{nm})$. 


\section{Color}

The application of unpaired t-test revealed significant differences of $\Delta a(p<0.05), \Delta b(p<0.05)$ and $\Delta E(p<0.05)$ for the enamel and dentin substrates, with greater variation of $\Delta \mathrm{b}$ and $\Delta \mathrm{E}$ for dentin specimens. $\Delta \mathrm{L}$ was not significantly different ( $p>0.05$ ). Table 2 shows the color coordinates and differences of all tested substrates.

Figures 3 and 4 show the spectral curves of mean values of all specimens, before and after whitening, where an increased reflection in the range of wavelengths near the blue $(410-460 \mathrm{~nm})$ can be observed.

\section{Chemical Characterization}

Enamel and dentin elemental analysis with SEM-EDS was used to assess changes in $\mathrm{C} / \mathrm{Ca}, \mathrm{C} / \mathrm{P}, \mathrm{O} / \mathrm{C}$ and $\mathrm{Ca} / \mathrm{P}$ ratios after whitening treatment. Table 3 presents the ratios before and after the bleaching procedure. Only $\mathrm{Ca} / \mathrm{P}$ ratio for enamel substrate presented reduction after the bleaching therapy. The other ratios remained similar after the whitening.

\section{Discussion}

It remains unknown why and how fluorescence of teeth may change with whitening (7), so the effect of whitening on the fluorescence of dental tissues was studied in this report. Dentin samples presented decrease in fluorescence values after whitening. Fluorescence intensity of enamel

Table 1. Mean and standard deviation of fluorescence (F.U.) before and after whitening and results of Tukey's test

\begin{tabular}{lccccc}
\hline \multirow{2}{*}{ Substrate } & \multicolumn{2}{c}{ Baseline measurement } & & \multicolumn{2}{c}{ Final measurement } \\
\cline { 2 - 3 } \cline { 5 - 6 } & Mean & SD & & Mean & SD \\
\hline Enamel & $50.63 \mathrm{Aa}^{*}$ & 13.59 & & $42.06 \mathrm{Aa}$ & 7.43 \\
Dentin & $158.00 \mathrm{Ab}$ & 31.59 & & $58.87 \mathrm{Ba}$ & 23.85 \\
\hline
\end{tabular}

* Different capital letters mean significant differences within rows $(p<0.05)$. Different lowercase letters mean significant differences within columns $(\mathrm{p}<0.05)$.

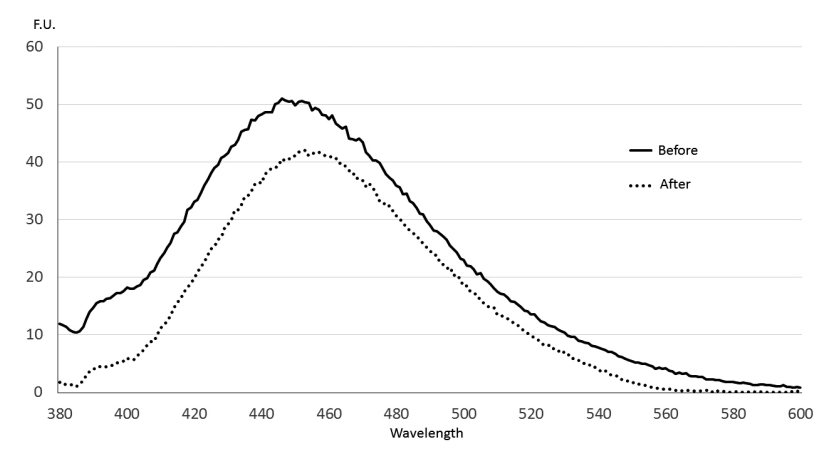

Figure 1. Averaged fluorescence intensity values of enamel, at excitation in $365 \mathrm{~nm}$. was $1 / 3$ of that from dentin and it was not affected by the whitening process.

Some previous studies $(1,15)$ reported that organic components of dental tissues are responsible for fluorescence. Foreman (5) identified two fluorophores extracted from normal dentin and indicated that they are primarily bonded to the organic constituent with possible secondary bonding to calcium. However, Spitzer and ten Bosch (1) found that enamel has different luminescing entities, which depend on emission wavelength and they concluded that hydroxyapatite does not play an important role in enamel luminescence and tryptophan is responsible for fluorescence. Armstrong (4) suggested that the fluorescence in human dentin may originate from inorganic complex with some organic components. In the present study, the significant reduction of minerals detected on enamel and similar mineral content in dentin, after the bleaching therapy, corroborates previous findings that report no influence of hydroxyapatite on fluorescence (1) and fluorescence in dentin depends on its organic contents (4). On the other hand, the mineral loss observed in enamel might have contributed to tooth whitening, as previously reported (16).

After whitening, fluorescence intensity of dentin samples decreased. Eimar et al. (17) observed that hydrogen peroxide oxidizes organic structure. Thus, whitening promoted oxidization of proteins and the resulting oxidized proteins could have lost their fluorescence capacity.

Enamel presented lower fluorescence than dentin at baseline, as previously reported by others (3). Moreover, whitening on enamel did not affect its fluorescence. Ten Bosch and Booij (15) observed that fluorescence in enamel is not due to any specific single component, and fluorescence change may be ascribed to interactions between different fluorophores within the dental tissues.

Some studies about fluorescence of dental materials have been conducted using an indirect method of assessment. The fluorescence is assessed by color measurement with

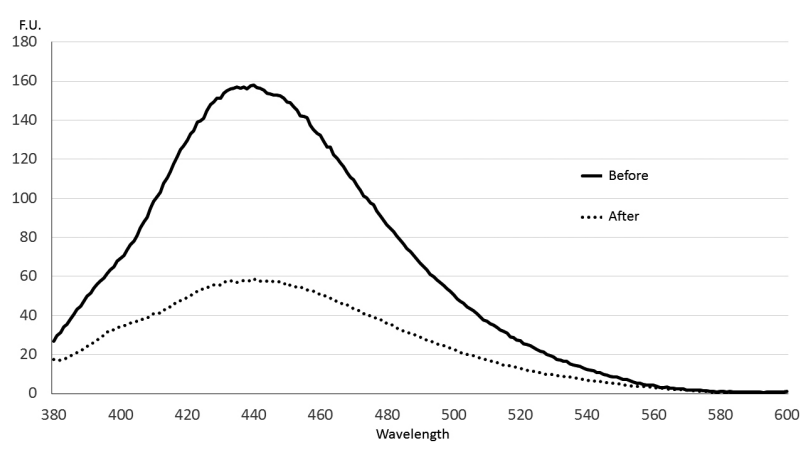

Figure 2. Averaged fluorescence intensity values of dentin, at excitation in $365 \mathrm{~nm}$. 
the inclusion and exclusion of UV component of the illuminant D65 $(18,19)$. Thus, fluorescence was evaluated for its influence on color of the substrate. In this study, a direct method (spectrofluorophotometer) was used a. The advantage of this method is that it is possible to choose a specific excitation wavelength and obtain emission spectra for that particular wavelength. Here was chosen the 365 $\mathrm{nm}$ excitation wavelength, since emission spectra near the "blue region" (440-460) could be observed (Figs. 1 and 2) (20). Da Silva et al. (21) also used a direct method, but they used a spectrometer coupled to optical fiber.

To know the influence of whitening on the color and

Table 2. Mean and Standard deviation (SD) data of $\mathrm{L}^{*}, \mathrm{a}^{*}, \mathrm{~b}^{*}, \Delta \mathrm{L}, \Delta \mathrm{a}, \Delta \mathrm{b}$ and $\Delta \mathrm{E}$ for enamel and dentin

\begin{tabular}{|c|c|c|c|c|c|c|c|c|c|}
\hline \multirow{2}{*}{ Substrate } & \multirow{2}{*}{ Coordinate } & \multicolumn{2}{|c|}{$\begin{array}{c}\text { Baseline } \\
\text { measurement }\end{array}$} & \multicolumn{2}{|c|}{$\begin{array}{l}\text { Final } \\
\text { measurement }\end{array}$} & \multicolumn{2}{|c|}{$\Delta$} & \multicolumn{2}{|c|}{$\Delta \mathrm{E}$} \\
\hline & & Mean & $\mathrm{SD}$ & Mean & SD & Mean & SD & Mean & SD \\
\hline \multirow{3}{*}{ Enamel } & $\mathrm{L}$ & 83.30 & 1.27 & 84.49 & 1.09 & 1.19 & 1.65 & \multirow{3}{*}{8.31} & \multirow{3}{*}{1.96} \\
\hline & a & -1.08 & 0.35 & -2.62 & 0.34 & -1.54 & 0.54 & & \\
\hline & $\mathrm{b}$ & 9.71 & 2.14 & 1.87 & 1.49 & -7.85 & 2.17 & & \\
\hline \multirow{3}{*}{ Dentin } & $\mathrm{L}$ & 85.14 & 1.43 & 86.17 & 1.46 & 1.03 & 2.10 & \multirow{3}{*}{10.37} & \multirow{3}{*}{3.34} \\
\hline & a & -1.95 & 0.41 & -2.00 & 0.22 & -0.05 & 0.42 & & \\
\hline & $\mathrm{b}$ & 18.41 & 3.48 & 8.33 & 0.76 & -10.08 & 3.40 & & \\
\hline
\end{tabular}

Table 3. Elemental ratios for dentin and enamel before and after whitening procedure and results of $\mathrm{t}$ test. Asterisk $(*)$ denotes statistical differences.

\begin{tabular}{|c|c|c|c|c|c|c|c|c|}
\hline & \multicolumn{2}{|c|}{$\mathrm{C} / \mathrm{Ca}$ at $\%$} & \multicolumn{2}{|c|}{$\mathrm{C} / \mathrm{P}$ at $\%$} & \multicolumn{2}{|c|}{ 0/C at $\%$} & \multicolumn{2}{|c|}{$\mathrm{Ca} / \mathrm{P}$ at $\%$} \\
\hline & Before & After & Before & After & Before & After & Before & After \\
\hline Dentin & $\begin{array}{c}1.81 \\
(0.26)\end{array}$ & $\begin{array}{c}1.78 \\
(0.30)\end{array}$ & $\begin{array}{c}3.16 \\
(0.49)\end{array}$ & $\begin{array}{c}3.11 \\
(0.50)\end{array}$ & $\begin{array}{c}2.0 \\
(0.15)\end{array}$ & $\begin{array}{c}2.37 \\
(0.32)\end{array}$ & $\begin{array}{c}1.75 \\
(0.04)\end{array}$ & $\begin{array}{c}1.75 \\
(0.01)\end{array}$ \\
\hline Enamel & $\begin{array}{c}0.75 \\
(0.06)\end{array}$ & $\begin{array}{c}0.65 \\
(0.06)\end{array}$ & $\begin{array}{c}1.39 \\
(0.13)\end{array}$ & $\begin{array}{c}1.17 \\
(0.12)\end{array}$ & $\begin{array}{c}4.18 \\
(0.39)\end{array}$ & $\begin{array}{c}5.21 \\
(0.59)\end{array}$ & $\begin{array}{l}1.86^{*} \\
(0.01)\end{array}$ & $\begin{array}{l}1.80^{*} \\
(0.02)\end{array}$ \\
\hline
\end{tabular}

fluorescence of dental substrates, enamel and dentin were separately analyzed in the present study. The values of $\Delta \mathrm{L}$ were positive in all whitened groups, which means that $L^{*}$ values increased during the course of the experiment. As with regards to $b^{*}$ values, were observed negative changes, i.e., $b^{*}$ values diminished during the course of the experiment, reflecting in a reduced specimen yellowness in the specimens. Hydrogen peroxide promoted a whitening of enamel and dentin substrates. As expected, strong changes of $b^{*}$ values were observed in dentin and enamel specimens. This is in agreement with previous studies, which observed that both enamel and dentin could be whitened by whitening agents in different degrees $(8,22)$. Moreover, the outcomes also demonstrated that dentin experienced larger color changes than enamel, indicating that dentin was easier to be whitened in direct contact with whitening agent. However, Ma et al. (23) observed more efficacy of enamel whitening than dentin. And some studies observed whitening effects of dentin specimens, but application of whitening gel was through the enamel $(22,24)$.

The spectral curves of mean values presented for each experimental group before and after bleaching (Figs. 3 and 4) show an increased reflection in the range of wavelengths near the blue, especially in the enamel specimens. These data confirm the higher values of the $b^{*}$ coordinate, as previously observed $(9,25)$. The coloring pigments within an object will absorb different wavelengths of light, allowing other wavelengths to scatter out the object. This selective wavelength absorption and reflection is the color source

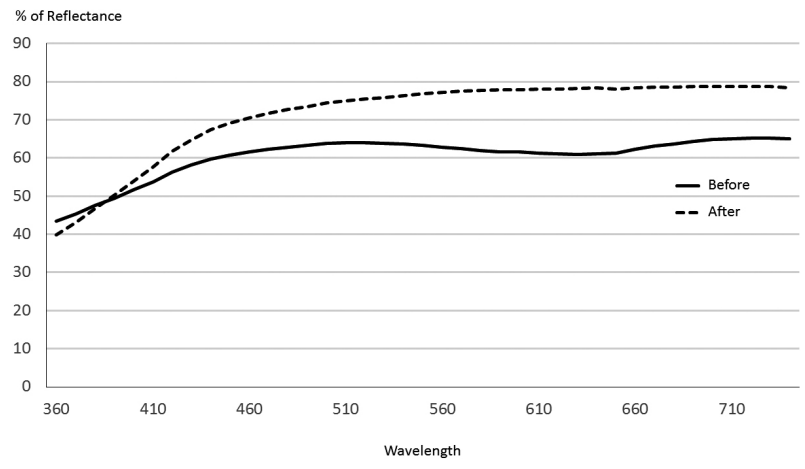

Figure 3. Averaged spectral curves of enamel before and after whitening with hydrogen peroxide.

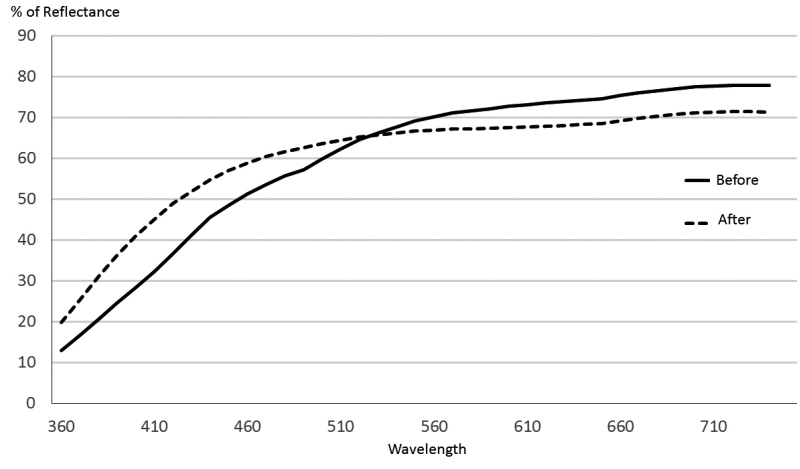

Figure 4. Averaged spectral curves of dentin before and after whitening with hydrogen peroxide. 
of the objects. Since blue-green lights are absorbed by the yellowish chromogens within enamel, the reflectance in these wavelengths is lower in unbleached teeth (25). A previous study showed a gradually increased reflectance in the 400-500 nm wavelengths for bovine enamel after the bleaching process (26).

Previous studies found different wavelength excitation and emission of fluorescence for dentin and enamel (27). As regards the tooth, whitening shifts tooth color from yellow to white and reflectance increases in the 400-500 $\mathrm{nm}$ wavelengths (26). In the present study, a decrease in fluorescence after bleaching therapy was observed. That decrease, from the perspective of apparent tooth color, would present contrary effect than the one obtained with tooth bleaching. The ideal scenario would be represented by the sum of light emission in the blue range, a fact that would improve bleaching outcomes. Further studies should be performed to understand the interaction of tooth selffluorescence and color, and also to develop products and techniques able to sum the above-mentioned effects of dental tissues reflectance.

Both null hypotheses were rejected, since whitening $\vec{\sigma}$ by hydrogen peroxide induced significant decrease in \pm fluorescence of tooth dentin and promoted significant color changes in dentin and enamel with more accentuated outcomes in dentin.

\section{Resumo}

0 objetivo deste estudo foi avaliar o efeito do clareamento com peróxido de hidrogênio na fluorescência e cor do esmalte e da dentina bovina. Vinte e cinco discos de dentina e 25 discos de esmalte, com $6 \mathrm{~mm}$ de diâmetro e $1 \mathrm{~mm}$ de espessura, foram obtidos. A fluorescência direta (Espectrofluorometria) e cor (espectrofotometria) foram avaliados. Depois da leitura inicial de cor e fluorescência, os espécimes foram imersos em solução de peróxido de hidrogénio a 35\% (HP) durante $1 \mathrm{~h}$. Este procedimento foi repetido após 7 dias. $\mathrm{E}$ as medições de fluorescência e de cor finais foram realizados após a segunda imersão. A caracterização química de 5 espécimes adicionais também foi realizada. Os dados foram submetidos à ANOVA de medidas repetidas e teste de Tukey para a fluorescência Teste e teste $t$ não pareado para a cor e os componentes químicos $(p<0,05)$. A fluorescência diminuiu significativamente nos espécimes de dentina após o clareamento. 0 esmalte apresentou fluorescência mais baixa do que a dentina na leitura inicial, mas esse parâmetro não diminuiu após o clareamento. Foram observadas alterações de cor para ambos os substratos, com significativamente maior efeito de clareamento em dentina $(A E=10,37)(p<0,001)$. 0 clareamento com peróxido de hidrogênio provocou diminuição significativa na fluorescência da dentina e promoveu alterações de cor significativas na dentina e esmalte com resultados mais pronunciados em dentina.

\section{References}

1. Spitzer D, Bosch JJ. The total luminescence of bovine and human dental enamel. Calcif Tissue Res 1976;201-208.

2. Benedict $\mathrm{HC}$. A note on the fluorescence of teeth in ultra-violet rays. Science 1928;67:442.

3. Hoerman KC, Mancewicz SA. Phosphorescence of calcified tissues. Arch Oral Biol 1964;9:517-534.

4. Armstrong WG. Fluorescence characteristics of sound and carious human dentine preparations. Arch Oral Biol 1963;8:79-90.

5. Foreman PC. The excitation and emission spectra of fluorescent components of human dentine. Arch Oral Biol 1980;25:641-647.

6. Hafstrom-Bjorkman $U$, Sundstrom $F$, ten Bosch JJ. Fluorescence in dissolved fractions of human enamel. Acta Odontol Scand 1991;49:133-138.

7. Gotz H, Duschner $H$, White DJ, Klukowska MA. Effects of elevated hydrogen peroxide 'strip' bleaching on surface and subsurface enamel including subsurface histomorphology, micro-chemical composition and fluorescence changes. J Dent 2007;35:457-466.

8. Caneppele $T M$, Borges $A B$, Torres $C R$. Effects of dental bleaching on the color, translucency and fluorescence properties of enamel and dentin. The European Journal of Esthetic Dentistry 2013;8:200-212.

9. Borges $A B$, Zanatta RF, Barros AC, Silva LC, Pucci CR, Torres CR. Effect of hydrogen peroxide concentration on enamel color and microhardness. Oper Dent 2015;40:96-101.

10. Jiang $T, M a X$, Wang $Y$, Tong $H$, Shen $X$, Hu $Y$ et al.. Investigation of the effects of $30 \%$ hydrogen peroxide on human tooth enamel by Raman scattering and laser-induced fluorescence. J Biomed Opt 2008;13:1419.

11. Torres $C R$, Wiegand $A$, Sener $B$, Attin T. Influence of chemical activation of a $35 \%$ hydrogen peroxide bleaching gel on its penetration and efficacy - in vitro study. J Dent 2010;38:838-846.

12. Sulieman M, Addy M, Macdonald E, Rees JS. The bleaching depth of a $35 \%$ hydrogen peroxide based in-office product: a study in vitro. J Dent 2005;33:33-40.

13. Cartagena $A F$, Parreiras SO, Loguercio AD, Reis A, Campanha NH. Inoffice bleaching effects on the pulp flow and tooth sensitivity - case series. Braz Oral Res 2015;29:

14. Joiner A. The bleaching of teeth: a review of the literature. J Dent 2006;34:412-419.

15. Booij $M$, ten Bosch JJ. A fluorescent compound in bovine dental enamel matrix compared with synthetic dityrosine. Arch Oral Biol 1982;27:417-421.

16. Li $\mathrm{Q}, \mathrm{Xu} B \mathrm{BT}, \mathrm{Li} \mathrm{R}, \mathrm{Yu} \mathrm{H}$, Wang YN. Quantitative evaluation of colour regression and mineral content change of bleached teeth. J Dent 2010;38:253-260.

17. Eimar $H_{1}$ Siciliano $R$, Abdallah MN, Nader SA, Amin WM, Martinez $\mathrm{PP}$, et al.. Hydrogen peroxide whitens teeth by oxidizing the organic structure. J Dent 2012;40 Suppl 2:e25-33.

18. Lim YK, Lee YK. Fluorescent emission of varied shades of resin composites. Dent Mater 2007;23:1262-1268.

19. Lee YK, Lu H, Powers JM. Changes in opalescence and fluorescence properties of resin composites after accelerated aging. Dent Mater 2006;22:653-660.

20. Matsumoto H, Kitamura $\mathrm{S}$, Araki T. Autofluorescence in human dentine in relation to age, tooth type and temperature measured by nanosecond time-resolved fluorescence microscopy. Arch Oral Biol 1999:44:309-318.

21. Silva $T$, Oliveira $H$, Severino $D$, Balducci I, Huhtala $M$, Goncalves $S$. Direct spectrometry: a new alternative for measuring the fluorescence of composite resins and dental tissues. Oper Dent 2014;39:407-415.

22. Wiegand A, Drebenstedt $S$, Roos M, Magalhaes AC, Attin T. 12-month color stability of enamel, dentine, and enamel-dentine samples after bleaching. Clin Oral Investig 2008;12:303-310.

23. Ma X, Li R, Sa Y, Liang S, Sun L, Jiang T, et al.. Separate contribution of enamel and dentine to overall tooth colour change in tooth bleaching. J Dent 2011;39:739-745.

24. Kugel G, Petkevis J, Gurgan S, Doherty E. Separate whitening effects on enamel and dentin after fourteen days. J Endod 2007;33:34-37.

25. Markovic L, Fotouhi $K$, Lorenz $H$, Jordan RA, Gaengler P, Zimmer S. Effects of bleaching agents on human enamel light reflectance. Oper Dent 2010;35:405-411.

26. Kwon YH, Huo MS, Kim KH, Kim SK, Kim YJ. Effects of hydrogen peroxide on the light reflectance and morphology of bovine enamel. J Oral Rehabil 2002;29:473-477.

27. Spitzer D, Bosch JT. The absorption and scattering of light in bovine and human dental enamel. Calcif Tissue Res 1975;17:129-137. 